\title{
Linguistic Legitimation of Political Events in Newspaper Discourse
}

\author{
Marwah Kareem Ali (Corresponding author) \\ School of Education \& Modern Languages, College of Arts and Sciences \\ University Utara Malaysia, 06010 Sintok, Kedah, Malaysia \\ E-mail: marwakareem16@yahoo.com \\ Anne A. Christopher \\ School of Education \& Modern Languages, College of Arts and Sciences \\ University Utara Malaysia, 06010 Sintok, Kedah, Malaysia \\ E-mail: althea@uum.edu.my \\ Munif Zarirruddin Fikri B. Nordin \\ Centre for General Studies, College of Arts and Sciences \\ University Utara Malaysia, 06010 Sintok, Kedah, Malaysia \\ E-mail:munif@uum.edu.my
}

Doi:10.7575/aiac.alls.v.7n.4p.76

URL: http://dx.doi.org/10.7575/aiac.alls.v.7n.4p.76
Received: 15/03/2016

Accepted: 08/05/2016

\begin{abstract}
This paper examines the discursive structures employed in legitimizing the event of U.S. forces withdrawal from Iraq and identifies them in relation to linguistic features. It attempts to describe the relation between language use and legitimation discursive structures in depicting political events. The paper focuses on the political event of U.S. forces' withdrawal from Iraq in the English newspaper issued in Iraq. The study shows the way in which journalists express their values and attitudes concerning this critical event. Consequently, this requires a critical discourse analysis (henceforth, CDA) to analyse news articles in the Iraqi English newspaper: The Kurdish Globe (henceforth, KG) newspaper. Accordingly, the study presents a qualitative content analysis of newspaper articles to identify the legitimation discursive structures and their linguistic features. It is found that the main discursive structures of legitimation employed in the KG newspaper are: authorization, rationalization, and moral evaluation. Besides, there were five verb processes used to represent this legitimation, including material, verbal, relational, mental, and existential.
\end{abstract}

Keywords: Critical discourse analysis, legitimation discursive structures, linguistic features, newspaper discourse, systemic functional linguistics

\section{Introduction}

Recently, newspaper discourse attracts the researchers' attention in the critical analysis field, particularly in relation to political issues (Farahani \& Ahmadian, 2014; Sadeghi, Hassani, \& Jalali, 2014). The essence of the newspaper discourse has changed. Thus, news articles in newspapers can be analysed to disclose the underlying intentions hidden behind the discursive construction of them (Sadeghi et al., 2014). Newspapers occupy an important role in any modern society since they address its various issues. The language employed in the newspaper does not simply convey the information that it overtly indicates. Language is, as asserted by Wodak (2001), a medium of domination and social power so that language is a suitable medium for uncovering hidden ideologies intended to construct social norms and values (Fairclough, 1995; van Dijk, 1996, 2001; van Leeuwen, 1996).

As well, the linguistic features used in the depiction of certain political events in newspapers, such as the political event of U.S. forces' withdrawal from Iraq, can be an important tool to legitimize these events. van Leeuwen (2008) argued that the discursive constructions of legitimation can be recognized through certain occurrences of text which may barely denote the legitimized practice or can be covered through detailed prescriptive or descriptive explanations of the institutions and practices they legitimize. The relation between language use and legitimation discursive structure can reveal the hidden ideologies under the words of journalists, yet there still more investigation needs to be done to identify this relation in the newspaper discourse.

\section{Problem Statement and Aims of the Study}

In fact, the analysis of legitimation strategies has been studied previously, but these studies focused on showing the strategies of legitimation employed in newspapers to legitimize an event or policy without revealing the linguistic features used to represent them. Therefore, this paper aims at identifying the linguistic features used in depicting the 
event of U.S. forces' withdrawal from Iraq in relation to the legitimation discursive structures employed in KG newspaper to legitimize this event. As well, it aims to examine the relation between the linguistic features of newspapers texts and legitimation structures in revealing hidden ideologies and values.

\section{Review of Literature}

\subsection{Newspaper and Critical Discourse Analysis}

Although it is regarded to be an old-fashion news media, the newspaper is still the main category of news coverage and it is the preferable one than other media forms (Youssefi, Kanani, \& Shojaei, 2013). Besides its role in informing and transmitting different issues, the newspaper presents a great amount of details related to the news, events descriptions, and analysis of their significance and effect. Newspapers have a crucial part in portraying social and national issues (Mahmood, Javed, \& Mahmood, 2011). Such issues bear ideological values hidden under the words chosen to represent them. These values are revealed through the use of CDA (Fairclough, 1995).

CDA has been applied in many studies in relation to newspaper discourse. CDA contributes to the field of linguistic studies in media discourses either spoken or written as it is focused on discovering hidden meanings, the relationship between language and context, the power of language use in different disciplines, in addition to highlighting texts as reflecting ideological, social, cultural, and political ideologies (Fairclough, 1995; van Dijk, 1995). Hence, Fairclough (1992) defines CDA as a systematic investigation of "opaque relationships of causality and determination between (a) discursive practices, events and texts, and (b) wider social and cultural structures, relations and processes" to reveal the way in which such events, practices and texts take place and how they are ideologically categorized by power relations (p. 135).

\subsection{Language Use in Newspaper Discourse}

The language use has an important role in the news writing system as it reflects the ability of the journalist/reporter to portray events in a beneficial way. In 1980, Harris clarified that newspapers bear the meaning of communication and sociality through the language use. Language is the best means of communication as it reflects our social and human activities. Through language use, we can express what we think and do either in spoken or written discourses (Harris, 1980; Richardson, 2007; Taiwo, 2007), it does not reflect our reality, but it also creates reality (Taiwo, 2007). Others, like Pennycook (2004), identified newspaper's language as a means of informing and representing various trends in social interaction. Bell (1991) and Popp (2006) agreed on the notion which depicts newspapers as institutions for language formation and realization. Therefore, in general, the realization of cultural, political, social, ideological, and economic issues should care for the role of language use in news media discourse, particularly in press, as the relationship between media and language use is an important one in relation to critical and analytical studies (Shojaei, Youssefi, \& Hosseini, 2013). According to Roksvold's (2010) viewpoint, the investigation of news language is an interesting field since it is incorporated into daily life, but its hidden processing is unknown for us.

Language use is revealed through the linguistic features which constitute the syntactic, semantic, and pragmatic structures. These features are used to clarify the events being depicted in newspaper articles. Such features are represented by the language meta-functions as highlighted by Halliday's (2014) SFL approach, namely ideational, interpersonal, and textual metafunctions.

\subsection{Language MetaFunctions}

The first metafunction of language is ideational. It is represented by the transitivity system which involves participants, processes, and circumstances. As well, it has six types of processes formed by verbs, including material (happening and doing), mental (affection and thinking), behavioural (behaving), relational (attributing and identifying), verbal (saying and asking), and finally existential (being) (Halliday \& Matthiessen, 2014). These processes require participants functioning in accordance with the type of process. In material process, the participants function as Actors, Goals, and Recipients; in the mental process, they function as Sensors and Phenomenon; in the behavioural process as behaviours; in the attributive relational process as Carriers and Adjectives whereas in identifying relational process as Token (Holders) and Values; in the verbal process as Sayer, Targets, and Verbiage; and finally in the existential process as Existent. In addition, the circumstances refer to the adverbial and prepositional phrases which clarify the event in terms of time, place, manner, cause and result, and conditional aspects (Halliday \& Matthiessen, 2014).

The interpersonal metafunction illustrates the mood and modality of the sentence. The sentence mood is either declarative (involving Subject + Finite sequence) or interrogative (involving Finite+ Subject sequence). Modality refers to the degree of certainty or obligation using the modal auxiliary verbs in the present tense (will, shall, can, may, must) and past tense (would, should, could, might). The third function is textual. This function is represented by the use of references, ellipsis, and conjunctions (Halliday \& Matthiessen, 2014).

\subsection{Legitimation and its Discursive Structures}

Legitimation is considered to be among the most effective ways that make things accepted and commonly known in a society. This is achieved through language or, more accurately, discourses. Consistent with van Leeuwen (2008), legitimation is a prominent function of language use and discourse. It is obviously a complex social (and political) act, and it is typically accomplished by text or talk. Currently, the popular news media play a substantial role in the processes of legitimation owing to its "power to influence knowledge, beliefs, values, social relations, and social identities" (Fairclough, 1995: 2). To become generally accepted, the information about innovative practices must be 
distributed within the institutional field. Therefore, the newspaper is a reliable tool for propagating new activities and making them publicly accepted.

Legitimation has a number of discursive structures or strategies which are described as "specific, not always intentional or conscious, ways of employing different discourses or discursive resources to establish legitimacy" (Vaara, Tienari, \& Laurila, 2006: p. 794) or illegitimacy. They can be used in either predetermined or unprompted way. According to Van Leeuwen \& Wodak (1999), legitimation is realized through four main strategies. These are authorization, moral evaluation, rationalization and mythopoesis. They are defined as "way in which language functions and is used for the construction of legitimacy" (Vaara, \& Tienar, 2008: p. 988). Authorization is recognized by referring to the appropriate (personal and impersonal) authority as subject, e.g. "Because I say so" or "According to the rule". Rationalization is realized by referring to the value of a particular social practice that is generally accepted or referring to general beliefs within a particular social environment; for instance, major religions. In addition, moral evaluation refers to a certain system of values, developing the ethical foundation for legitimation in the social context, for example, politeness and humanity. The last category of legitimation strategies is mythopoesis. It stresses legitimation obtained through narrative or by relating the investigated practice to the past or future through storytelling (Van Leeuwen and Wodak, 1999).

\section{Methodology}

This paper focuses on identifying the linguistic features employed in the legitimation of the political event of U.S. forces withdrawal from Iraq. The sample is represented by four excerpts taken from two news articles issued in the Iraqi English newspaper $(\mathrm{KG})$ during December 2011 which represents the period of the formal and complete withdrawal of U.S. forces from Iraq after nine years of U.S. occupation of Iraq following the 2003 war. The study is carried out using the qualitative content analysis through a critical lens. Hence, Fairclough's (1995) approach to CDA is used to analyse the excerpts selected from KG newspaper. Besides, Halliday's SFL approach is used to identify the linguistic features of the selected excerpts and van Leeuwen's (2008) model of legitimation discursive structures employed in the newspaper to legitimize this mentioned event.

\section{Data Analysis}

The excerpts were analysed following the three dimensions of CDA, namely: description, interpretation, and explanation (Fairclough, 1995). In the first dimension, the excerpts were described linguistically to identify the linguistic features in accordance with Halliday's (2014) SFL approach. The second dimension interpreted the use of legitimation discursive structures in relation to models of van Leeuwen (2008) and van Leeuwen and Wodak (1999). The last dimension explained the use of certain lexical and syntactic structures to convey certain hidden political ideologies.

\subsection{Authorization}

According to van Leeuwen and Wodak (1999), authorization is realized through indicating the appropriate (personal and impersonal) authority as subject, e.g. "Because I say so" or "According to the rule".

\subsubsection{Personal Authority}

In this case, the legitimation authority is assigned to people who have a power status or role in a certain institution (van Leeuwen, 2008).

Excerpt (1): "It is true the U.S. forces will pull out of Iraq, but the United States' commitment towards Iraq and Kurdistan Region will remain present," Biden said.

(KG: December 03, 2011; under the Headline: Biden assures Iraqi leaders of U.S. commitment)

This direct quotation shows the continuation of United States' commitment towards Iraq and Kurdistan region after withdrawing its military forces. Linguistically, (Biden) is represented as the Sayer of the verbal process which is realized through the verb (said) representing the projected clause of quoting. It is represented in declarative mood indicating a promise of U.S. government to support Iraq and Kurdistan region in military and political aspects. The two modal finite verbs (will) could be analysed as expressing certainty with some impression of futurity. These two sentences were joined using the conjuncture $(b u t)$ to negate the U.S. abandoning Iraq after the withdrawal of its forces. This functions as a statement on what will be the policy of U.S. administration regarding the future of its relation with Iraq after withdrawing its military forces. It is noteworthy that the definite article $(t h e)$ and the possessive $\left(s^{\prime}\right)$ are used to presuppose meanings in this quotation (Richardson, 2007). So, (the U.S. forces) presupposes the existence of American forces in Iraq, (the United States' commitment) presuppose the existence of U.S. government's support for Iraq and Kurdistan region. In addition, the nominal phrase (Kurdistan Region) which is added to Iraq using the additive conjuncture (and) presupposes that U.S. government considers Kurdistan region as an autonomous state not only as an Iraqi north region. This, in turn, is in the political agenda of the newspaper which concentrates on Kurdish issues and its autonomy.

This quotation legitimizes the event of U.S. forces withdrawal from Iraq on the grounds of authorization taking the form of personal authority. This authorization is enhanced by the direct quotation of U.S. vice president Joe Biden's statement as a political source representing the backgrounded subject of the sentence to legitimize this event by denoting the continuous relationship between U.S. and Iraq after the withdrawal of U.S. forces. U.S. vice president Joe Biden has the power, authority as well as legitimacy to ensure the event of U.S. forces withdrawal from Iraq. This implies that a formal official with authority and liability is assuring the U.S. continuous relations with Iraq. Based on this statement, the U.S. forces withdrawal will not affect the Iraq-U.S. relations so that it is legitimized. 
Implicitly, this quotation reveals that Iraq still needs the support of U.S. government which invaded Iraq in 2003 and then occupied it for more than eight years. However, U.S. government and its forces are represented as supporter not occupier. Consequently, this is in the interest of political practices since it reveals the dominance of U.S. over Iraq. As well, it represents the U.S. government as the powerful authority involved in this event as it undertakes the decision of withdrawal from Iraq.

\subsubsection{The Authority of Conformity}

In the case of conformity, the answer to the "why" question is "because that's what everybody else does" or "because that's what most people do." In most cases, it is recognized through high-frequency modality (van Leeuwen, 2008).

Excerpt (2): Iraqi Deputy Prime Minister Hussain al-Shahristani said Iraqis were glad that U.S. troops were leaving. "I think we are all happy that the American soldiers are returning home safely to their families, and we are also confident that the Iraqi people and their armed forces and police are in a position now to take care of their own security."

(KG: December 17, 2011; under the Headline: Dawn or dusk: A new chapter in Iraq)

This excerpt represents the withdrawal of U.S. forces from Iraq with a positive tone relying on the emotional words (glad and happy) which express happiness. This excerpt is represented in two ways; i.e. as indirect quotation and then enhanced with the use of direct quotation of the exact words as said by the Iraqi deputy Prime Minister Hussain alShahristani. Linguistically, (Hussain al-Shahristani) is the Sayer of the verbal process (said) stating the happiness of Iraqis because of the withdrawal of U.S. forces. The verbiage also consists of participants and processes. The relational process is formed by the verb (were) attributing the adjective (glad) to (Iraqis) who represents the Carrier. As well, the relative clause which at the same time identifies the reason behind Iraqis' happiness (that U.S. troops were leaving) bears a material process of doing in the form of verbal phrase (were leaving) done by (U.S. troops) the Actor. Turning to the direct quotation used to enhance and emphasise the reported speech, the personal pronoun $(I)$ which refers to (Hussain al-Shahristani) is the Sensor of the mental process involving the cognition verb (think) and the relative clause represents its phenomenon. Here, the pronoun $(I)$ reflects individuality showing that Hussain al-Shahristani expresses his thinking as a politician in the Iraqi government concerning the event of U.S. forces withdrawal from Iraq. In addition, the inclusive pronoun (we), in the first position, refers to Iraqis including the Sensor himself while in the second position it refers to Hussain al-Shahristani and other Iraqi politicians showing his consistency with other members in the government regarding their confidence in the ability of Iraqi security system in keeping Iraq secure after U.S. forces withdrawal from Iraq. It formulates the Carrier of the relational process using the verb (are) attributing the adjectives (happy and confident) to its participant (we). This excerpt is represented in the active declarative mood. The clauses are joined using the additive conjuncture (and).

Concerning the legitimation practice, it can be said that this excerpt reveals three types of authorization, including personal authority represented by the Sayer (Hussain al-Shahristani), expert authority formulated by the mental process (I think), and the authority of conformity shown in (Iraqis) and (we are all happy). Therefore, this event is legitimized because all Iraqis are glad and happy.

The excerpt bears a positive tone towards the withdrawal event. It is depicted in a sentimentalised way which highlights the confidence of Iraqi government in its people and security system as being able to secure Iraq in the post-U.S. troops period indicated by (now) which refers to the present period following U.S. forces withdrawal from Iraq. AlShahristani's statement bears an ideological belief of having strong security forces capable of defending and protecting Iraq without depending on the help of American troops. This, in turn, emphasises on Iraq's independence and sovereignty.

\subsection{Rationalization}

Rationalization has two main types, including instrumentality legitimizing practices by referring to their uses, goals and effects; and theoretical rationality which legitimizes practices by referring to a regular order of things. The second type is applied in the KG newspaper under the subcategory of definition in which one activity is defined in terms of another moralized activity. The definition category is realized through generalizing and objectifying the activities. The relation between these activities should either be attributive (using verbs such as is and constitutes) or signifying (using verbs such as means, signals, and symbolizes) (van Leeuwen, 2008).

Excerpt (3): Before traveling to Erbil, Biden officially celebrated the end of the Iraq War and said the two countries are now in a new phase of their ties. He highlighted that the remaining 13,000 U.S. soldiers will pull out by the end of the year. "Our troops... are leaving Iraq and we are embarking on a new path together, a new phase in this relationship... between two sovereign nations".

(KG: December 03, 2011; under the Headline: Biden assures Iraqi leaders of U.S. commitment)

This excerpt depicts the positive aspect following the event of U.S. forces withdrawal from Iraq. Linguistically, the main participants involved in this excerpt are: Biden and He (both Actor and Sayer, respectively), the end of the Iraq War (Goal), Our troops (Actor), Iraq (Goal), we (Actor), a new path together and a new phase in this relationship (Goal). Concerning processes, celebrated (material of event process), said and highlighted (the verbal process of saying and asserting), are leaving (the material process of doing), are embarking on (the material process of happening). The circumstances are denoted by the use of time adverbs in (Before travelling to Erbil) and (by the end of the year). The sentences are in active declarative mood and the modal verb (will) used in the sentence presupposes certainty and confirms the withdrawal of U.S. troops in the near future. The sentences are joined by (and) which is used to extend or 
add more information. U.S. vice president Joe Biden and the U.S. troops are used in the subject position as being the powerful authority involved in the withdrawal event.

In relation to the legitimation discursive practice applied in this excerpt, it is represented by definition which is a subcategory of theoretical rationalization. In other words, the direct quotation of Biden's speech legitimizes the event of U.S. forces withdrawal by defining the new situation of both countries regarding their relations after this event "Our troops... are leaving Iraq and we are embarking on a new path together, a new phase in this relationship... between two sovereign nations". So, the U.S. forces withdrawal from Iraq enhanced the relationship between Iraq and U.S. governments.

Lexically, the reporter used the nominal phrase (the end of the Iraq War) which presupposes two meanings, including the U.S. forces withdrawal from Iraq and accusation of Iraq in being responsible for this war. Hence, the U.S. forces withdrawal is not expressed explicitly but it is embodied in the mentioned phrase. In Iraqi context, the war is defined either as 'the 2003 war', 'the U.S.-led war', 'the U.S. and its coalition war', or (to be more neutral) 'the U.S.-Iraq war'. Iraqis use these expressions to accuse the U.S. government of causing war against Iraq. On the contrary, the newspaper represents Iraq as the only responsible for this war. Moreover, the use of manner adverb of quality (officially) means that the event was formal in terms of its nature. The use of the adjective (new) in these phrases (a new path together, a new phase in this relationship) presupposes that both countries have experienced old or past hammerings (Richardson, 2007). Finally, the personal pronoun (we) (refers to Iraq and U.S. governments) is an inclusive pronoun used to show consistency between the two countries as well as equality. This is enhanced by the phrase of (two sovereign nations), i.e. showing sovereignty of Iraq and U.S.

\subsection{Moral Evaluation}

It is based on values, rather than imposed by some kind of authority without further justification. It can be expressed in different ways, including evaluation, abstraction, and analogies. In the KG newspaper, abstraction was employed as a way of legitimizing the withdrawal of U.S. forces. In abstraction, it refers to practices (or to one or more of their component actions or reactions) in abstract ways that "moralize" them by distilling from them a quality that links them to discourses of moral values (van Leeuwen, 2008).

Excerpt (4): The flag of American military forces in Iraq was lowered in Baghdad during an official ceremony, bringing nearly nine years of U.S. military operations in Iraq to a formal end. At its peak, U.S. troops numbered 170,000; now, only 4,000 remain for another two weeks. With the U.S. troop withdrawal, a new chapter begins in Iraq.

(KG: December 17, 2011; under the Headline: Dawn or dusk: A new chapter in Iraq)

This excerpt depicts U.S. forces' withdrawal from Iraq formally after nearly nine years of U.S. occupation following its war against Iraq in 2003. As a reaction to this event, Iraq experiences a new phase in the history of its conflicts with U.S. In terms of transitivity, The flag of American military forces in Iraq represents (Goal) of the verbal phrase (was lowered) which forms the material process of withdrawal event taking place in Baghdad (location circumstance) during an official ceremony (duration circumstance) bringing nearly nine years of U.S. military operations in Iraq to a formal end (result circumstance); U.S. troops represents the Carrier of the attributive relational process represented by (numbered and remain) and a new chapter represents (Existent) of the existential process formed by (begins); for another two weeks is (duration circumstance) and in Iraq is (location circumstance). The sentences are in active declarative mood in except for the first sentence which is constructed in passive voice with no agent.

The event of U.S. forces withdrawal from Iraq is legitimized through the discursive structure of moral evaluation in the form of abstraction. This type of legitimation discursive practice is shown in (bringing nearly nine years of U.S. military operations in Iraq to a formal end) and (With the U.S. troop withdrawal, a new chapter begins in Iraq). The editor refers to the result of U.S. forces withdrawal from Iraq as the formal end of nine years of U.S. military operations in Iraq which leads to the beginning of new chapter in the history book of prolonged conflicts between U.S. and Iraq. Accordingly, the event of U.S. forces withdrawal from Iraq is legitimized since it ends the military operations and results in a new phase in Iraq.

In the first sentence of this excerpt, it is clear that the editor focused on the Goal of the material process which is transformed to the subject position of the passive sentence without mentioning its agent. Therefore, the editor considers (The flag of American military forces in Iraq) to be a more important aspect of the story than who was actually doing it. This reveals the importance of event rather than its agent and hence, the subject is omitted leaving its role unknown, i.e. Who did lower the flag of American military forces in Iraq? Who was the responsible for this event? Did it happen under the authority of U.S. government or Iraqi government? This type of transformation from active into passive structure removes a sense of specificity and precision from the sentence (Richardson, 2007). This, in turn, serves political practices since such transformation can remove important political implications and in this case hiding the dominance of U.S. government over events related to Iraqi affairs.

\section{Results and Discussion}

The event of U.S. forces withdrawal from Iraq which happened in 2011 has been an important event in Iraq since it has resulted in ending the military presence of U.S. forces in Iraq after nine years of occupation following the US-led war in 2003 against Iraq. The U.S. forces withdrawal from Iraq has been a controversial event, i.e. some Iraqi political parties agreed on it whereas others did not. So, this inspired the researcher to study the depiction of this event in the newspaper articles. The main aims of this study were to identify the linguistic structures used in legitimizing this controversial 
event and to examine the relation between the linguistic structures and legitimation structures in revealing the political practices hidden under lexical and syntactic structures.

Based on the analysis carried out using CDA, it is found that three types of legitimation discursive structures were employed in the KG newspaper to legitimize the U.S. forces' withdrawal from Iraq. The main discursive structures of legitimation were: authorization (personal, expert, and conformity), rationalization (theoretical rationalization in the form of abstraction), and finally moral evaluation (definition). Linguistically, the legitimation structures were formed using different processes. The following tables illustrate the main processes that were used in legitimizing the event of U.S. forces withdrawal from Iraq:

Table 1. Legitimation of U.S. forces withdrawal from Iraq through material process

\begin{tabular}{|c|c|c|c|c|c|c|}
\hline \multirow[t]{2}{*}{ No. } & \multirow{2}{*}{$\begin{array}{l}\text { Legitimation } \\
\text { Categories }\end{array}$} & \multirow{2}{*}{$\begin{array}{l}\text { Legitimation } \\
\text { Subcategory }\end{array}$} & \multicolumn{4}{|c|}{ Linguistic Representation of Legitimation } \\
\hline & & & Participants & Role & Verbs & Type \\
\hline \multirow[t]{2}{*}{1} & \multirow[t]{2}{*}{ Authorization } & $\begin{array}{l}\text { Personal } \\
\text { Authority }\end{array}$ & the U.S. forces & Subject (Goal) & $\begin{array}{l}\text { will pull } \\
\text { out }\end{array}$ & $\begin{array}{l}\text { Verb of } \\
\text { doing }\end{array}$ \\
\hline & & $\begin{array}{l}\text { Authority of } \\
\text { Conformity }\end{array}$ & $\begin{array}{l}\text { the American } \\
\text { soldiers }\end{array}$ & Subject (Goal) & $\begin{array}{l}\text { are } \\
\text { returning } \\
\text { home }\end{array}$ & $\begin{array}{l}\text { Verb of } \\
\text { doing }\end{array}$ \\
\hline \multirow[t]{4}{*}{2} & \multirow[t]{4}{*}{ Rationalization } & \multirow{4}{*}{$\begin{array}{l}\text { Theoretical } \\
\text { rationalization } \\
\text { (Definition) }\end{array}$} & Biden & Subject (Actor) & celebrated & $\begin{array}{l}\text { Verb of } \\
\text { doing }\end{array}$ \\
\hline & & & $\begin{array}{l}\text { the remaining } \\
13,000 \text { U.S. } \\
\text { soldiers }\end{array}$ & Subject (Goal) & $\begin{array}{l}\text { will pull } \\
\text { out }\end{array}$ & $\begin{array}{l}\text { Verb of } \\
\text { doing }\end{array}$ \\
\hline & & & $\begin{array}{l}\text { Our troops (the } \\
\text { U.S. troops) }\end{array}$ & Subject (Goal) & are leaving & $\begin{array}{l}\text { Verb of } \\
\text { doing }\end{array}$ \\
\hline & & & $\begin{array}{l}\text { We (Iraq and } \\
\text { U.S. } \\
\text { governments) }\end{array}$ & Subject (Actor) & $\begin{array}{l}\text { are } \\
\text { embarking } \\
\text { on }\end{array}$ & $\begin{array}{l}\text { Verb of } \\
\text { doing }\end{array}$ \\
\hline 3 & $\begin{array}{l}\text { Moral } \\
\text { Evaluation }\end{array}$ & Abstraction & $\begin{array}{l}\text { The flag of } \\
\text { American } \\
\text { military forces } \\
\text { in Iraq }\end{array}$ & $\begin{array}{l}\text { Foregrounded } \\
\text { object (Subject of } \\
\text { the passive } \\
\text { sentence) (Goal) }\end{array}$ & $\begin{array}{l}\text { was } \\
\text { lowered }\end{array}$ & $\begin{array}{l}\text { Verb of } \\
\text { happening }\end{array}$ \\
\hline
\end{tabular}

In this table, three legitimation structures were employed using material process, including authorization, rationalization, and moral evaluation. It is clear that all sentences were related to actions performed by the U.S. government as being the powerful authority involved in this event embodied by its forces and its vice president Joe Biden. Almost all verbs used in depicting the actions were formulated using verbs of doing. This, in turn, reveals the dominance of U.S. government over Iraq.

Table 2. Legitimation through verbal process

\begin{tabular}{|c|c|c|c|c|c|c|}
\hline \multirow[t]{2}{*}{ No. } & \multirow{2}{*}{$\begin{array}{l}\text { Legitimation } \\
\text { Categories }\end{array}$} & \multirow{2}{*}{$\begin{array}{l}\text { Legitimation } \\
\text { Subcategory }\end{array}$} & \multicolumn{4}{|c|}{ Linguistic Representation of Legitimation } \\
\hline & & & Participants & Role & Verbs & Type \\
\hline \multirow[t]{2}{*}{1} & \multirow[t]{2}{*}{ Authorization } & $\begin{array}{l}\text { Personal } \\
\text { Authority }\end{array}$ & Biden & $\begin{array}{l}\text { Backgrounded } \\
\text { subject (Sayer) }\end{array}$ & said & $\begin{array}{l}\text { Quoting } \\
\text { verb }\end{array}$ \\
\hline & & $\begin{array}{l}\text { Authority of } \\
\text { Conformity }\end{array}$ & $\begin{array}{l}\text { Hussain al- } \\
\text { Shahristani }\end{array}$ & Subject (Sayer) & said & $\begin{array}{l}\text { Quoting } \\
\text { verb }\end{array}$ \\
\hline \multirow[t]{2}{*}{2} & \multirow[t]{2}{*}{ Rationalization } & \multirow{2}{*}{$\begin{array}{l}\text { Theoretical } \\
\text { rationalization } \\
\text { (Definition) }\end{array}$} & Biden & Subject (Sayer) & said & $\begin{array}{l}\text { Quoting } \\
\text { verb }\end{array}$ \\
\hline & & & He (Biden) & Subject (Sayer) & highlighted & $\begin{array}{l}\text { Assertive } \\
\text { verb }\end{array}$ \\
\hline
\end{tabular}

This table shows that only two legitimation structures were presented using verbal process, namely authorization and rationalization. The main active voice used to legitimize the U.S. forces withdrawal is related to the powerful authority involved in this event which is the U.S. government represented by its vice president Joe Biden. As well, the main quoting verb used in quoting and restating the statements is represented by the verb of saying (said) which refers to a 
neutral form of news reporting. Accordingly, this represents the objectivity practice as the journalists attempted to distance themselves from truth claims of the statements by relying on the statements of people in authority.

Table 3. Legitimation through relational process

\begin{tabular}{|c|c|c|c|c|c|c|}
\hline \multirow[t]{2}{*}{ No. } & \multirow{2}{*}{$\begin{array}{l}\text { Legitimation } \\
\text { Categories }\end{array}$} & \multirow{2}{*}{$\begin{array}{l}\text { Legitimation } \\
\text { Subcategory }\end{array}$} & \multicolumn{4}{|c|}{ Linguistic Representation of Legitimation } \\
\hline & & & Participants & Role & Verbs & Type \\
\hline \multirow[t]{4}{*}{1} & \multirow[t]{4}{*}{ Authorization } & $\begin{array}{l}\text { Personal } \\
\text { Authority }\end{array}$ & $\begin{array}{l}\text { the United States' } \\
\text { commitment }\end{array}$ & $\begin{array}{l}\text { Subject } \\
\text { (Carrier) }\end{array}$ & will remain & $\begin{array}{l}\text { Verb of } \\
\text { continuation }\end{array}$ \\
\hline & & $\begin{array}{l}\text { Authority of } \\
\text { Conformity }\end{array}$ & Iraqis & $\begin{array}{l}\text { Subject } \\
\text { (Carrier) }\end{array}$ & were & $\begin{array}{l}\text { Attributive } \\
\text { intensive verb }\end{array}$ \\
\hline & & & We (Iraqis) & $\begin{array}{l}\text { Subject } \\
\text { (Carrier) }\end{array}$ & are & $\begin{array}{l}\text { Attributive } \\
\text { intensive verb }\end{array}$ \\
\hline & & & $\begin{array}{l}\text { We (Hussain al- } \\
\text { Shahristani and } \\
\text { other Iraqi } \\
\text { politicians) }\end{array}$ & $\begin{array}{l}\text { Subject } \\
\text { (Carrier) }\end{array}$ & are & $\begin{array}{l}\text { Attributive } \\
\text { intensive verb }\end{array}$ \\
\hline 2 & $\begin{array}{l}\text { Moral } \\
\text { Evaluation }\end{array}$ & Abstraction & U.S. troops & $\begin{array}{l}\text { Subject } \\
\text { (Carrier) }\end{array}$ & $\begin{array}{l}\text { numbered } \\
\text { and remain }\end{array}$ & $\begin{array}{l}\text { Verbs of } \\
\text { attribution }\end{array}$ \\
\hline
\end{tabular}

The third table reveals the linguistic features used to identify the relational attributive process which has appeared five times representing authorization category (personal and conformity authority) and abstraction which is a subcategory of moral evaluation. This process is attributed to the United States' commitment and U.S. troops, the Iraqis and Iraqi politicians. This confirms that the majority of Iraqis and Iraqi politicians welcomed the withdrawal of U.S. forces from Iraq.

Table 4. Legitimation through mental process

\begin{tabular}{lllllll}
\hline No. & $\begin{array}{l}\text { Legitimation } \\
\text { Categories }\end{array}$ & \multirow{2}{*}{$\begin{array}{l}\text { Legitimation } \\
\text { Subcategory }\end{array}$} & \multicolumn{4}{l}{ Linguistic Representation of Legitimation } \\
\cline { 5 - 7 } & & Participants & Role & Verbs & Type \\
\hline 1 & Authorization & Authority & of & I (Hussain al- & Subject \\
& Expert & & Shahristani) & think & Verb of cognition \\
& & & & & & \\
\hline
\end{tabular}

This table shows that the mental process was used only one time representing the authorization category of legitimation on the basis of expert authority. Hence, van Leeuwen (2008) stated that the mental process is used to denote expert authority.

Table 5. Legitimation through existential process

\begin{tabular}{lllllll}
\hline No. & Legitimation & Legitimation & \multicolumn{4}{l}{ Linguistic Representation of Legitimation } \\
\cline { 4 - 6 } & Categories & Subcategory & Participants & Role & Verbs & Type \\
\hline 2 & Moral & Abstraction & a new chapter & $\begin{array}{l}\text { Subject } \\
\text { (Existent) }\end{array}$ & begins & $\begin{array}{l}\text { Verbs of } \\
\text { existence }\end{array}$ \\
\hline
\end{tabular}

The final table represents the use of the existential process to legitimize the U.S. forces withdrawal. This process is represented by a verb referring to existence. This presupposes that the withdrawal event has happened indeed. Consequently, Iraq is experiencing a new phase after the U.S. forces' withdrawal by which the U.S. military presence is ended.

\section{Conclusion}

This paper focused on identifying the linguistic features used to legitimize the U.S. forces' withdrawal from Iraq and the relation between the linguistic features and legitimation structures in revealing hidden ideologies. It is found that three legitimation structures were employed using five types of processes. The legitimation structures are authorization, rationalization, and moral evaluation. The most frequent structure of legitimation is the authority of conformity. In addition, the processes utilized in this legitimation are verbal, material, mental, relational, and existential. The material process is the most frequent process type in relation to legitimation structures followed by the relational and verbal processes, whereas the mental and existential processes were less frequent in the linguistic representation of U.S. 
forces' withdrawal. The linguistic features used to represent legitimation structures revealed the dominance of U.S. government over Iraq in relation to the future policies that will be undertaken after the withdrawal event.

\section{References}

Bell, A. (1991). The language of news media. Oxford: Blackwell.

Fairclough, N. (1992). Discourse and social change. Cambridge: Polity Press.

Fairclough, N. (1995). Critical discourse analysis: The critical study of language. London: Addison Wesley Publishing Company.

Farahani, E., \& Ahmadian, M. (2014). What is the truth ? A demonstration of language manipulation in two newspapers and the pedagogical implications. International Journal of Research Studies in Language Learning, 3(7), 89-100.

Halliday, M. A. K. \&, \& Matthiessen, C. M. I. M. (2014). Halliday's introduction to functional grammar (4 ${ }^{\text {th }}$ ed.). London and New York: Routledge.

Harris, R. (1980). The language makers. London: Duckworth.

Mahmood, M. A., Javed, S., \& Mahmood, R. (2011). A critical discourse analysis of the news headlines of budget of Pakistan FY 2011-2012. Interdisciplinary Journal of Contemporary Research in Business (IJCRB), 3(5), 120-129.

Pennycook, A. (2004). Performativity and language studies. Critical Inquiry in Language Studies: An International Journal, 1(1), 1-19.

Popp, R. K. (2006). Mass media and the linguistic marketplace: Media, language, and distinction. Journal of Communication Inquiry, 30(1), 5-20.

Richardson, J. E. (2007). Analysing newspapers: An approach from critical discourse analysis ( $1^{\text {st }}$ ed.). New York: Palgrave Macmillan.

Roksvold, T. (2010). Changes in newspaper language explored as changes in cultural norms. Intercultural Communication Studies, 19(3), 104-111.

Sadeghi, B., Hassani, M. T., \& Jalali, V. (2014). Towards (de-)legitimation discursive strategies in news coverage of Egyptian protest: VOA \& Fars news in focus. Procedia-Social and Behavioral Sciences, 98, 1580-1589.

Shojaei, A., Youssefi, K., \& Hosseini, H. S. (2013). A CDA approach to the biased interpretation and representation of ideologically conflicting ideas in Western printed media. Journal of Language Teaching and Research, 4(4), 858-868.

Taiwo, R. (2007). Language, ideology and power relations in Nigerian newspaper headlines. Nebula, 4(1), $218-245$.

Vaara, E., \& Tienar, J. (2008). A discursive perspective on legitimation strategies in multinational corporations. Academy of Management Review, 33(4), 985-993.

Vaara, E., Tienari, J., \& Laurila, J. (2006). Pulp and paper fiction: On the discursive legitimation of global industrial restructuring. Organization Studies, 27(6), 789-810.

Van Dijk, T. A. (1995). Discourse analysis as ideology analysis. Language and Peace, 10, 47-142.

Van Dijk, T. A. (1996). Discourse, power and access. In C. R. Caldas-Coulthard \& M. Coulthard (Eds.), Texts and practices: Readings in critical discourse analysis (pp. 84-104). London and New York: Routledge.

Van Dijk, T. A. (2001). Critical discourse analysis. In D. Schiffin, D. Tannen, \& H. Hamliton (Eds.), The handbook of discourse analysis (pp. 352-371). Oxford: Blackwell.

Van Leeuwen, T. (1996). The representation of social actors in discourse. In C. R. Caldas-Coulthard \& M. Coulthard (Eds.), Texts and practices: Readings in critical discourse analysis (pp. 32-70). London: Routledge.

Van Leeuwen, T. (2008). Discourse and practice: New tools for critical discourse analysis. Oxford: Oxford University Press.

Van Leeuwen, T., \& Wodak, R. (1999). Legitimizing immigration control: A discourse-historical analysis. Discourse Studies, 1(1), 83-118.

Wodak, R. (2001). What CDA is about - a summary of its history, important concepts and its developments. In R. Wodak \& M. Meyer (Eds.), Methods of critical discourse analysis (pp. 1-13). London: Sage.

Youssefi, K., Kanani, A. B., \& Shojaei, A. (2013). Ideological or international move? A critical discourse analysis toward the representation of Iran sanctions in Western printed media. Journal of Language Teaching and Research, $4(6), 1343-1350$. 